\title{
Effects of processing method and blend on some physicochemical properties and digestibility of flours made from selected cereals and legumes
}

\author{
Kouakou BROU ${ }^{1 *}$, Eugène J.P. N'Guessan KOUADIO ${ }^{2}$, Edmond Ahipo DUE ${ }^{2}$, \\ Sallert Konan KOUAME ${ }^{1}$, Kablan TANO ${ }^{2}$ and Gnakri DAGO ${ }^{1}$ \\ ${ }^{1}$ UFR-STA, Laboratoire de Nutrition et Sécurité Alimentaire. \\ ${ }^{2}$ UFR-STA, Laboratoire de Biochimie et Technologie alimentaire. \\ ${ }^{*}$ Corresponding author, 02 BP 801 Abidjan 02,Université d'Abobo-Adjamé, Côte d'Ivoire (UFR-STA). \\ E-mail : bkd_ci2007@yahoo.fr
}

\begin{abstract}
In the way to set up an appropriate weaning food, the effect of various treatments such as germination, fermentation and supplementation with legumes on millet flour quality was investigated. Untreated and treated samples of flours were monitored for their nutritional properties and in vitro digestibility. Results showed an important effect of treatment on flour proximate composition and digestion. In fact, proteins, lipids, ash, minerals $(\mathrm{Ca}, \mathrm{Mg})$ contents and energy density were well-enhanced when millet flour was supplemented by soybean. Values were respectively $24.5 \%, 12.1 \%, 2.66 \%, 0.23$ and $0.15 \mathrm{mg} / 100 \mathrm{~g}$ and $408,98 \mathrm{kcal} / 100 \mathrm{~g}$. Values for the untreated flour were $9.63 \%, 3.6 \%, 2.5 \%, 0.067$ and $0.093 \mathrm{mg} / 100 \mathrm{~g}$ and $403.98 \mathrm{kcal} / 100 \mathrm{~g}$ respectively for the same parameters. Total tocopherols with contents of 820.71 and $799.1 \mathrm{mg} / \mathrm{kg}$ were highest in germinated and soybean supplemented flours. But soybean supplemented flour had the lowest digestibility rate contrarily to the germinated one. However, this formulation appears as the best treatment for improving infant feeding.

(C) 2009 International Formulae Group. All rights reserved
\end{abstract}

Key words: Composite flours, cowpeas, digestibility, fermentation, germination, millet flour, soybean.

\section{INTRODUCTION}

Weaning foods are fluids or semiliquid foods introduced into infant diets in order to gradually but eventually replace breast milk by table foods. Such supplementations are necessary because as the infant grows, nutrients provided by breast milk become insufficient to support adequate maintenance and development if used as sole source of nourishment. This period occurs ideally between 4-6 months after birth and several authors have documented growth faltering as early as 3 months in infants in developing countries (Kluvitse, 1999). This period coincides with the peak production of breast milk by the nursing mother despite the infant increasing rate of growth. Thus, infant may be weaned with either special formulated foods or with regular table foods that are more nutritious and could be prepared to be easily ingested and digested.

In developing countries, complementary foods are based on local staple foods, usually cereals that are processed into porridges. Apart from their bulkiness reported as probable factor in the aetiology of malnutrition (Ljungqvist et al., 1981), cerealbased gruels are of poor nutritional value and therefore have some implications in the incidence of protein-energy malnutrition, a major cause of high infant mortality rate in developing countries (Eka, 1978).

To fight against worldwide
increasing problem of protein energy 
malnutrition, inexpensive sources of protein, locally produced have become a potential solution pursued for scientists. The low-cost weaning formulations must ideally be derived from dietary staples in the region of interest, affordable to the part of population vulnerable to malnutrition and readily available in sufficient quantity.

Cereals are important staple foods used in traditional systems in Côte d'Ivoire. Most of them are used in infant diets. However, they show some limitations due to their low protein content. Thus, there is a particular need for high-quality weaning foods in lessdeveloped countries and much effort has been focused on methods of producing nutritious foods from plant sources (Bressani, 1975). In this way, cowpea (Vigna unguiculata) and soybean, due to their availability and popularity for infant food supplementation, become an option for use in weaning foods in developing countries (Guiro et al., 1987). Ferrier et al. (1975) showed that variety of soy-cereals blends have been developed with varying degrees of success. Thus, the combination of these cereals and legumes in appropriate proportions will enable the complementation of amino acids limiting in either grain.

Additionally, several processing technologies which include fermentation and germination have been put into practice to improve the nutritional properties of cereals.

Apart from improving the nutritive value of the resulting foods by reducing to some extent the flatulence and nutritional stress factors of legumes (Barampama and Simard, 1994), these technologies are appropriate to household and village or rural levels and leads to low-cost, stable and pathogen-free foods (Egounlety, 1996).

As far as it concerned germination, it is a complex metabolic process during which lipids, carbohydrates, and storage proteins are broken down in order to obtain the energy and necessary amino acids for the plant's development (Jachmanian et al., 1995; Ferreira et al., 1995). It is necessary to evaluate how germination affects essential nutrients.

This study was carried out to assess the effects of some treatments (germination, fermentation and blends formulations) on nutritional properties and in vitro digestibility of millet flours.

\section{MATERIALS AND METHODS \\ Plant material}

The plant material used in this study was constituted of cereals and legumes: yellow maize (Zea mays), millet (Pennisetum glaucum (L) R.BR) grains, cowpea (Vigna unguiculata) and soya (Glycine max). Cereals and leguminous were bought on various markets of Abidjan in the southern area of Côte d'Ivoire. These cereals and leguminous were selected because of the frequency of their production and their intense utilization for the preparation of local infant weaning foods.

\section{Chemicals}

Chemicals used in this study were: Trichloro-acetic acid (TCA), Folin-ciocateus reagent, hydrochloric acid, ethanol, n-hexane (MERCK), dinitro-acetic salicylic acid (DNS) (Fluka AG), cooper II sulphate, potassium sodium tartrate (LABCM company), sodium hydroxide, of potassium permanganate (OMPLOU CHEMISTRY (OMC)), bovine albumin serum (BSA), sulphuric acid 96\%, sodium carbonate, sodium acetate, zinc acetate (PANRACS). All chemicals were analytical grade. Enzyme used for digestibility test was a thermostable enzyme from Bacillus licheniformis obtained from Novo Laboratoires, Denmark.

\section{Methods \\ Preparation of dry flours}

Millet seeds (Pennisetum glaucum) used for this study were bought from local retailers in Abobo city (Côte d'Ivoire). They were thoroughly cleaned and divided into five equal parts.

- One part (1 kg) was not subjected to any treatment. It served as control for digestion test and chemical analyse. It constituted the flour FMNT.

- Another part of $1 \mathrm{~kg}$ was soaked in water in ratio of $1: 3(\mathrm{p} / \mathrm{v})$ for over $24 \mathrm{~h}$ and then left for spontaneous fermentation during $48 \mathrm{~h}$. The fermented millet seeds were dried at $45{ }^{\circ} \mathrm{C}$ 
during $48 \mathrm{~h}$ and ground to pass a $200 \mu \mathrm{m}$ screen to obtain the flour FMF.

- One other $\mathrm{kg}$ was overnight immersed in water $1: 3(\mathrm{p} / \mathrm{v})$ and then was spread on trays lind with cloth at room temperature $\left(25{ }^{\circ} \mathrm{C}\right)$ for one week. It was kept wet by frequent water spraying. After germination, seeds were separately dried at $45{ }^{\circ} \mathrm{C}$ until a constant weight and ground to pass a $200 \mu \mathrm{m}$ screen. The flour was named FMG.

The two remaining parts of millet seeds were used as support for weaning food formulations.

The untreated, germinated and fermented flours were hammer - milled (70 mesh screen) into fine flour. The raw fermented aliquot was dried as before, remilled, packaged in polystyrene and frozen until analysis. Maize seeds were also ground into flour through hammer mill fitted with 0,5 $\mathrm{mm}$. This flour was stored in polyethylene bags for formulated weaning food.

Legumes

Cowpea and soya seeds were immersed in tap water for a night at $25^{\circ} \mathrm{C}$ to remove the seed coasts. The excess water was drained and seed were removed. The seeds were then dried at $45{ }^{\circ} \mathrm{C}$ in oven for $48 \mathrm{~h}$ and were then decorticated through a mill. Decorticated cowpea and soya seeds were combined with millet or maize.

\section{Weaning food formulation}

Weaning food containing cereals and legumines was formulated using laboratory method (Table 1). The cereal-legume composites were agglomerated then roasted into low-moisture weaning foods. Formulate composite 1 (FC1) consisted of cowpea $(65 \%)$, cereal flour (30\%) and sugar (5\%). Formulate composite 2 (FC2) was made up of soya (45\%), maize flour (25\%), millet flour (25\%) and sugar $(5 \%)$. Sugar was added to improve taste. All the products were milled using grinding with a $0.5 \mathrm{~mm}$ mesh sieve and then stored at $4{ }^{\circ} \mathrm{C}$ for further analysis.

\section{Biochemical analysis of flours}

Dry matter content of the different flours was determined by drying them to constant weight in oven at $105{ }^{\circ} \mathrm{C}$ according to AOAC (1990). Ash content was determined by incineration of flour at $500{ }^{\circ} \mathrm{C}$ in an oven. Total carbohydrates were determined according to the method of Bertrand and Thomas (1910). Starch content was deducted by calculating the difference between total carbohydrates content and total sugars content. The fatty matter was extracted with the soxhlet using $n$-hexane. Total nitrogen was determined according to Kjeldahl's method (AOAC, 1990). Crude protein was calculated as $\mathrm{N} \times 6,25$. For tocopherol quantification, duplicate samples of the extracted flour oil ( 50 $\mathrm{mg}$ ) were transferred into a $5 \mathrm{ml}$ brown volumetric flask, and dissolved in $100 \% \mathrm{n}$ hexane. The $\mathrm{Fe}, \mathrm{Ca}$ and $\mathrm{Mg}$ contents were simultaneously determined by flame atomic absorption spectrophotometry (Perkin-Elmer analysis 100, USA) following wet digestion of sample with $\mathrm{HNO}_{3}$ and $\mathrm{HCLO}_{4}$ (Barhisel and Bertsch, 1982). The chromatographic separation of $\alpha-, \beta-, \gamma$-, and $\delta$-tocopherols was achieved on a normal phase equisorb silica column $(250 \times 4.0 \mathrm{~mm}$ i.d, $5 \mu \mathrm{m}$, Cluzeau, Sainte-Foy-La-Grande, France) coupled with a fluorometric detector monitored at an excitation wavelength of $290 \mathrm{~nm}$ and an emission wavelength of $330 \mathrm{~nm}$ (multi $\lambda$, Waters 2475, Milford, MA). The mobile phase was $n$-hexane/propan-2-ol $(99.5 / 0.5$ $\mathrm{v} / \mathrm{v})$ at a flow rate of $1 \mathrm{~mL} / \mathrm{min}$. The injection volume was $20 \mu \mathrm{L}$. The quantification of each tocopherol was based on an external calibration using the standard molecules of $\alpha$-, $\beta-, \quad \gamma-$, and $\delta$-tocopherols (Sigma-Aldrich, Steinheim, Germany).

Determination of the energy value in kilocalorie

The energy value (VE) of the flours was calculated with $4 \mathrm{kcal} / \mathrm{g}$ for carbohydrates, $4 \mathrm{kcal} / \mathrm{g}$ for proteins and 9 $\mathrm{kcal} / \mathrm{g}$ for lipids according to Livesey (1995).

$\mathrm{VE}=(9 \times$ Lipids $(\%))+(4 \times$ Proteins $(\%))+$ $(4 \times$ Carbohydrates $(\%))$.

\section{In vitro digestibility of flours}

Amylolytic enzyme from bacterial source was employed. In vitro digestibility of different flours consisted of a reaction between alpha-amylase and an amount of flour at $1 \%(\mathrm{w} / \mathrm{v})$. The reaction medium was constituted as follow: $400 \mu \mathrm{l}$ of acetate buffer (100 mM, pH 5), $25 \mu \mathrm{l}$ of alpha-amylase and $75 \mu \mathrm{l}$ of $1 \%$ of flour. The mixture was then incubated at $37{ }^{\circ} \mathrm{C}$ for 3 hours in a Marie- 
bath. Aliquots of the reaction medium were taken every $10 \mathrm{~min}$ for reducing sugars determination according to the method of Bernfeld (1955).

\section{Statistical analysis}

Results are expressed as mean \pm standard deviation. One-way ANOVA was used to test the effects of treatments at $\mathrm{P}<$ 0.05. The non parametric test of DUNCAN was used for the analysis of the difference between means using STATISTICA software (Statistica, 99th Edition, France) at the significance of $5 \%$.

\section{RESULTS}

\section{Proximate composition of flours}

Chemical analyses carried out to determine the proximate and selected mineral composition of the untreated millet flour (FMNT), fermented millet flour (FMF), germinated millet flour (FMG) and the blends formulations 1 (FC1) and 2 (FC2) are summarised in table 2 and 3. Results show that dry matter contents were very high in the different studied flours. Values varied between $93.33 \%$ for FMF and $96.64 \%$ for FC1 which value is slightly higher than the others $(\mathrm{P}<0.05)$. Total ash contents were also variable in the flours with highest values $(2.66 \%)$ in FC2. Flours also constituted good sources of carbohydrates. For this parameter, values were $72.12 \%, 76.17 \%, 64.20,38.21 \%$ and $50.48 \%$ respectively for untreated flour, germinated flour, fermented flour and blends formulations 1 and 2. Treatments significantly $(\mathrm{P}<0.05)$ affected fat matter contents and the highest values were obtained when millet flour was supplemented with soybean (12\%) and cowpea $(7.63 \%)$. Crude proteins contents were also significantly $(\mathrm{P}<0.05)$ enhanced particularly for the soybean supplemented flour (FC2) with a rate of $24.50 \%$. The FC2 protein content constituted the two quantities of the other flours with the lowest value for the fermented $(8.17 \%)$ and germinated flours $(9.63 \%)$. Results also indicated that flours contained high rates of starch with significant differences $(\mathrm{P}<0.05)$ between all the flours. The untreated flours (FMNT) showed the highest starch content $(65.22 \%)$, followed by the fermented flours FMF (57.77\%).

\section{Minerals}

Mineral contents of different flours expressed in percentage of dry matter are presented in table 3. Calcium and magnesium increased with cowpea and soya fortified flours. The value varied between $0.15-0.25 \%$ and $0.12-0.15 \%$ respectively for calcium and magnesium. Iron rate was not significantly different within all groups, except the fermented flour which concentration of $0.14 \%$ was the lowest.

\section{Tocopherols}

Tocopherols contents in the different preparations are presented in table 3. Total tocopherols were highest in FC1 (1154.54 $\mathrm{mg} / \mathrm{kg})$, FMG $(820.71 \mathrm{mg} / \mathrm{kg})$ and FC2 (799.1 $\mathrm{mg} / \mathrm{kg}$ ). $\quad \beta$-tocopherol was not detected in FMNT, FMF and FC1, but a substantial part was present in FMG $(15.3 \mathrm{mg} / \mathrm{kg})$ and FC2 $(34.13 \mathrm{mg} / \mathrm{kg})$. In all the flours, $\gamma$-tocopherol was the major component except FMG where the concentration of $\alpha$-tocopherol was higher than $\gamma$-tocopherol content.

\section{Flours digestibility}

Figure 1 shows results of different flours digestion with alpha-amylase. From 0 to $45 \mathrm{~min}$, the germinated millet flour had a higher starch digestibility compared to other flours, with a digestion rate about $70 \%$. It was followed by untreated and fermented flours with a percentage of hydrolysis about $40 \%$. As far as it concerned FC1 and FC2, their percentage of hydrolysis was low, about 30 and $22 \%$ respectively. From $100 \mathrm{~min}$, the degree of hydrolysis reached $80 \%, 72 \%, 65 \%$, $55 \%$ and $30 \%$ respectively for FMG, FMNT, FMF, FC1 and FC2. Among the flours, the lowest degrees of digestibility were observed when using the blends flours compared to FMNT, FMG and FMF. Starch hydrolysis increased with time and showed significant differences related to the technological processes on the one hand and on the other hand to supplemented ingredients. 
Table 1: Ingredient rations of designed formulations (\%).

\begin{tabular}{lccccc}
\hline Ingredients & FMNT & FMG & FMF & FC1 & FC2 \\
\hline Millet & 95 & 95 & 95 & 65 & 25 \\
Maize & - & - & - & - & 25 \\
Cowpea & - & - & - & 30 & - \\
Soya & - & - & - & - & 45 \\
Sugar & 5 & 5 & 5 & 5 & 5
\end{tabular}

FMNT: Untreated millet flour, FMG: Germinated millet flour, FMF: fermented millet flour, FC1: cowpeas supplemented flour, FC2: Soya supplemented flour.

Table 2: Proximate composition of different formulations.

\begin{tabular}{lccccc}
\hline Parameters & FMNT & FMG & FMF & FC1 & FC2 \\
\hline Dry matter (\%) & $94.67 \pm 0.3^{\mathrm{a}}$ & $93.5 \pm 0.5^{\mathrm{a}}$ & $93.33 \pm 0.3^{\mathrm{a}}$ & $96.64 \pm 1.3^{\mathrm{b}}$ & $93.72 \pm 0.8^{\mathrm{a}}$ \\
Ash (\%) & $2.5 \pm 0.1^{\mathrm{a}}$ & $2.3 \pm 0.04^{\mathrm{b}}$ & $2.25 \pm 0.05^{\mathrm{a}}$ & $2.33 \pm 0.46^{\mathrm{c}}$ & $2.66 \pm 0.54^{\mathrm{d}}$ \\
Carbohydrates (\%) & $72.56 \pm 0.5^{\mathrm{e}}$ & $76.17 \pm 0.9^{\mathrm{f}}$ & $64.20 \pm 0.7^{\mathrm{d}}$ & $38.21 \pm 0.9^{\mathrm{a}}$ & $50.48 \pm 0.6^{\mathrm{b}}$ \\
Proteins (\%) & $9,63 \pm 0.5^{\mathrm{c}}$ & $9.63 \pm 0.9^{\mathrm{c}}$ & $8.17 \pm 0.5^{\mathrm{b}}$ & $14 \pm 0.9^{\mathrm{d}}$ & $24.50 \pm 0.9$ \\
Lipids( \%) & $3.6 \pm 0.2^{\mathrm{d}}$ & $4.03 \pm 0.11^{\mathrm{b}}$ & $4.63 \pm 0.2^{\mathrm{a}}$ & $7.63 \pm 0.2^{\mathrm{c}}$ & $12.1 \pm 0.1^{\mathrm{e}}$ \\
Starch (\%) & $65.22 \pm 0.5^{\mathrm{e}}$ & $51.36 \pm 0.5^{\mathrm{c}}$ & $57.77 \pm 0.6^{\mathrm{d}}$ & $34.40 \pm 0.8^{\mathrm{a}}$ & $45.37 \pm 0.5^{\mathrm{b}}$ \\
Energy (kcal/100 g) & 403.98 & 395.6 & 331.15 & 277.87 & 408.98 \\
\hline The values are the mean \pm standard deviation of three measurements. The same letter registered in the same line indicates \\
that there is no significant difference between the samples for the parameter concerned (P > 0.05). FMNT: Untreated millet \\
flour, FMG: Germinated millet flour, FMF: fermented millet flour, FC1: cowpeas supplemented flour, FC2: Soya \\
supplemented flour.
\end{tabular}

Table 3: Mineral composition of different formulations.

\begin{tabular}{lccccc}
\hline $\begin{array}{l}\text { Minerals } \\
(\mathbf{g} / \mathbf{1 0 0} \mathbf{g})\end{array}$ & FMNT & FMG & FMF & FC1 & FC2 \\
\hline $\mathrm{Ca}$ & $0.067 \pm 0.006^{\mathrm{a}}$ & $0.09 \pm 0^{\mathrm{b}}$ & $0.057 \pm 0.006^{\mathrm{a}}$ & $0.15 \pm 0.02^{\mathrm{c}}$ & $0.23 \pm 0.02^{\mathrm{d}}$ \\
$\mathrm{Mg}$ & $0.093 \pm 0.006^{\mathrm{b}}$ & $0.09 \pm 0.01^{\mathrm{b}}$ & $0.05 \pm 0^{\mathrm{a}}$ & $0.12 \pm 0^{\mathrm{c}}$ & $0.15 \pm 0.006^{\mathrm{d}}$ \\
$\mathrm{Fe}$ & $0.23 \pm 0.03^{\mathrm{a}}$ & $0.24 \pm 0.05^{\mathrm{a}}$ & $0.14 \pm 0.03^{\mathrm{b}}$ & $0.25 \pm 0.02^{\mathrm{a}}$ & $0.26 \pm 0.04^{\mathrm{a}}$ \\
\hline
\end{tabular}

The values are the mean \pm standard deviation of three measurements. The same letter registered in the same line indicates that there is no significant difference between the samples for the parameter concerned $(\mathrm{P}>0.05)$. FMNT: Untreated millet flour, FMG: Germinated millet flour, FMF: fermented millet flour, FC1: cowpeas supplemented flour, FC2: Soya supplemented flour.

Table 4: Tocopherols content of different preparations.

\begin{tabular}{lccccc}
\hline Flours & \multicolumn{5}{c}{ Tocopherols content $(\mathbf{m g} / \mathbf{k g})$} \\
\cline { 2 - 5 } & Alpha & Beta & gamma & delta & $\begin{array}{c}\text { Total } \\
\text { tocopherols }\end{array}$ \\
\hline FMNT & $58.46 \pm 0.45^{\mathrm{a}}$ & 0 & $655.06 \pm 0.40^{\mathrm{a}}$ & $49.26 \pm 0.97^{\mathrm{a}}$ & $762.23 \pm 0.93^{\mathrm{a}}$ \\
FMG & $433.8 \pm 0.75^{\mathrm{b}}$ & $15.3 \pm 0.60^{\mathrm{a}}$ & $359.3 \pm 1.67^{\mathrm{b}}$ & $12.05 \pm 0.54^{\mathrm{b}}$ & $820.71 \pm 1.68^{\mathrm{b}}$ \\
FMF & $45.16 \pm 0.76^{\mathrm{c}}$ & 0 & $603.26 \pm 0.80^{\mathrm{c}}$ & $23.26 \pm 1.07^{\mathrm{c}}$ & $671.08 \pm 0.10^{\mathrm{c}}$ \\
FC1 & $43.86 \pm 0.15^{\mathrm{d}}$ & 0 & $808.43 \pm 1.32^{\mathrm{d}}$ & $301.58 \pm 0.38^{\mathrm{d}}$ & $1154.54 \pm 0.45^{\mathrm{d}}$ \\
FC2 & $145.2 \pm 0.72^{\mathrm{e}}$ & $34.13 \pm 0.32^{\mathrm{b}}$ & $467.33 \pm 1.26^{\mathrm{e}}$ & $154.61 \pm 0.85^{\mathrm{e}}$ & $799.10 \pm 0.12^{\mathrm{e}}$ \\
\hline The values are the mean \pm standard deviation of three measurements $(\mathrm{N}=3)$. The same letter registered in the same column \\
indicates that there is no significant difference between the samples for the parameter concerned (P > $>05)$. FMNT: \\
Untreated millet flour, FMG: Germinated millet flour, FMF: fermented millet flour, FC1: cowpeas supplemented flour, FC2: \\
Soya supplemented flour.
\end{tabular}




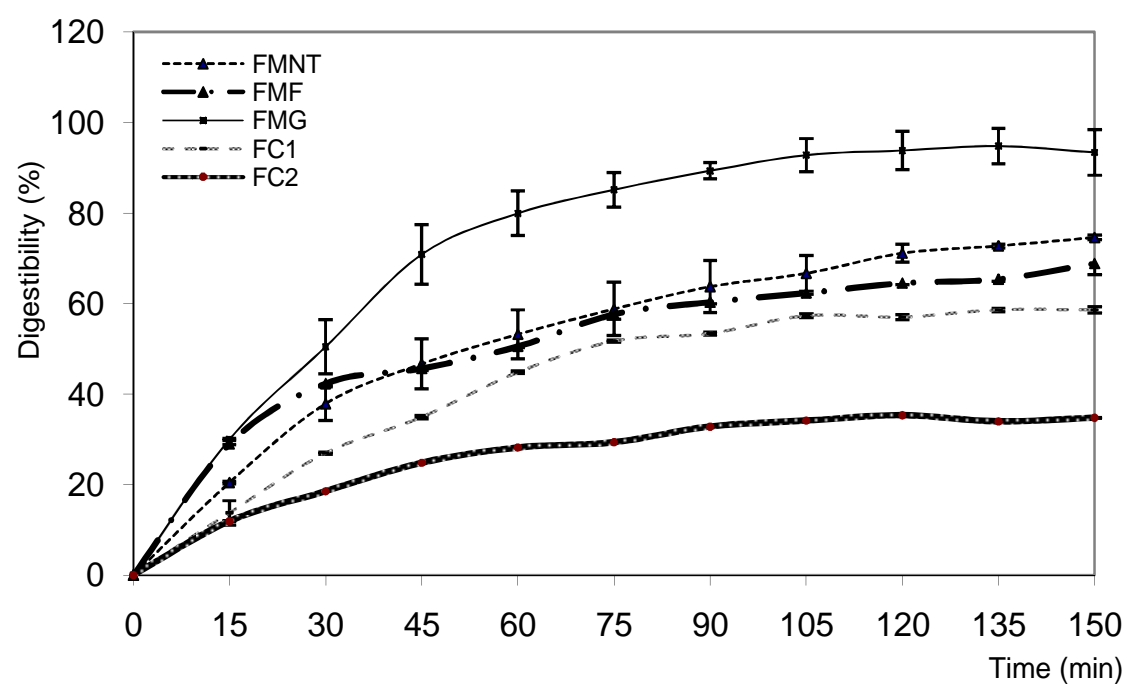

Figure 1: In vitro digestibility of different flours.

FMNT: Untreated millet flour, FMG: Germinated millet flour, FMF: fermented millet flour, FC1: cowpeas supplemented flour, FC2: Soya supplemented flour.

\section{DISCUSSION}

The results of this study indicate that dry matter contents were high and not significantly affected by the treatments. The low moisture of the five flours is a good indicator of their long shelflife (Kanu et al., 2009). These results were in agreement with those of Alabi and Anuonye (2007) and Inyang and Zakari (2008) who suggested that flour with low moisture could be preserved for a long time without risk of microbial proliferation.

Generally, all flours produced were rich in carbohydrates particularly for FMNT, FMG and FMF, and this could significantly satisfy the infant's energy needs, as cereal based-foods are essentially energy foods.

Fat matter contents were significantly affected by treatments and the highest values were obtained when millet flour was supplemented with soybean and cowpea. In fact, these legumes are rich in lipids and supplementing flours with them brings a substantial part of fatty matters. These high fat matter contents also play important roles in flours energy density. As we can see, energy density was highest $(408.98 \mathrm{kcal} / 100 \mathrm{~g})$ for FC2. However, fat contents were low for FMNT, FMG and FMF. This observation has also been reported by Inyang and Zakari (2008). The observed decrease might be due to the increased activities of the lipolytic enzymes during germination (Raham and Aal, 1986), which hydrolyse fats to fatty acids and glycerol. The simple products can be used for synthesis of carbohydrate and protein or as a source of energy for development of embryo. Similar observation was made by Obizoba and Nnam (2000). Inyang and Idoko (2006) also reported reduced fat content in malted millet for "Ogi" production and low lipid levels are known to increase shelf-life.

Crude proteins contents were also significantly enhanced particularly for the soybean supplemented flour (FC2). The FC2 protein content constituted the two quantities of the other flours with the lowest value for the fermented and germinated flours. This indicates that extensive breakdown of proteins occurred during both fermentation and germination processes. A similar observation was made by Egounlety (2003). The high 
protein contents of $\mathrm{FC} 2$ and FC1 was attributed to the addition of soy and cowpea (which contain about $39 \%$ of protein). Findings also showed that legume seeds are good sources of proteins and other nutrients for humans and animals consumption and their utilization in infant formula and other products has significantly solved nutrition problems among low income groups (Ikujenlola and Fashakin, 2005). Both food commodities had been recommended for infant feedings (Nnam, 2002). Moreover, according to Greenberg and Harting (1998) consumption of 17-25 $\mathrm{g}$ of soy protein a day reduces serum cholesterol to $9.3 \%$ on the average. Also low-density lipoprotein cholesterol (LDL) reduces to about $13 \%$ while the high density lipoprotein (HDL) cholesterol may not be affected. It is therefore clear that by eating $25 \mathrm{~g}$ of soy protein a day, the chances of falling victim to heart diseases are almost reduced to one-thirds. Nursing mothers with infants allergic to cow milk will find the soy-cereal meal an alternative (Greenberg and Harting 1998). Thus, results suggest that mixing millet with cowpeas can produce a significant improved food for young children. As far as it concerned FMG and FMF, the change in protein content may be attributed to the fact that water-soluble nitrogen was lost during soaking of seeds. Moreover, during germination a part of proteins was utilized for the growth and development of embryo (Wu and wall, 1980).

Ash content represents the total mineral content in food. Mineral contents significantly increased in composite flours. This was expected and is in agreement with literature report (Iwe and Onuh, 1992). The relative high mineral contents indicate that composite flours are good sources of minerals brought by the supplementation with soybean. According to certain investigators, cereals were deficient in many vital nutrients and therefore could not supply alone the necessary nutrient requirement for the rapid growth and development of children. So it appears necessary to complement them with legumes in order to improve their nutritional values (Malleshi et al., 1999). Calcium, magnesium and iron deficiencies in foods can lead to abnormal bone development and anemia (Akinyede and Amoo, 2009). They were appreciably present in adequate proportions needed for the body growth and cognitive development.

In all cases, $\gamma$-tocopherol was the major component except FMG where the concentration of $\alpha$-tocopherol was higher than $\gamma$-tocopherol content. As it is noticed, tocopherol contents were affected by treatments and supplementation on the one hand and on the other hand are susceptible to be lost through fermentation. Tocopherols are powerful antioxidants belonging to the family of vitamin E. Their high rate in foods is a great particular interest for the assessment oil quality. Tocopherols also protect essentially against oxydation of unsaturated fatty acids (UFA) (Fernando et al., 1998). In addition, tocopherols are chemically known as antioxidants that protect cellular membranes in the mammalian tissues from free radical damage. Thus, tocopherols content of weaning foods is particularly important since antioxidant status in kwashiorkor patients, as measured by plasma concentration of gluthation and vitamin $\mathrm{E}$, is significantly reduced (Sauerweli et al., 1997).

Among the flours, the lowest degrees of digestibility were observed when using the blends flours compared to FMNT, FMG and FMF. Starch hydrolysis increased with time and showed significant differences related to the technological processes on the one hand and on the other hand to supplemented ingredients. This is in agreement with reports of Van der Merwe et al. (2001) who studied the effect of processing on the digestibility of cereal foods. Moreover, differences in the in vitro digestibility of flours could be attributed to several factors including the proximate composition and the physical form of the starch (Hoover and Sosulski, 1985), protein- 
starch interactions, the physical form of food, the integrity of starch-containing cells, and presence of antinutritional factors. Topping and Clifton (2001) showed that the resistance of starch to digestion may be due to its intrinsic properties, the extent to which food is chewed, the result of changes during processing, retrogradation, chemical modification, or due to interactions with other food constituents, especially lipids. Granule characteristics considered influencing susceptibility to attack by $\alpha$-amylase include crystallinity, granule size and available specific surface, amylose to amylopectin ratio, porosity, structural non homogeneities and degree of integrity (Kong et al., 2003). The fact that cowpeas and soya have higher protein content than millet could also have been responsible for the lower starch enzymesusceptibility of supplemented flours. Protein structures encapsulating starch or covering starch granules surfaces would be expected to decrease the availability of starch to amylase in vitro (Asp and Björck, 1989). In addition, the longer the incubation time, the more starch particles were sufficiently gelatinized, what allows the digestive enzymes to exercise efficiently their activity.

\section{Conclusion}

The results of this study showed that various treatments of millet seeds including fermentation, germination and supplementation with legumes affect nutritional characteristics and digestibility of derivative flours. But supplementation by legumes particularly with soybean bestenhanced protein, lipid, ash, tocopherol and mineral contents. The resulting flour also constitutes a potential source of energy. With these advantages, this flour could be foreseeable to remedy the protein-energy malnutrition of which endures children in Côte d'Ivoire. However, complementary studies may be achieved to put in place more complete nutritional complement foods for developing country children which feeding must be improved.

\section{ACKNOWLEDGMENTS}

The authors are grateful to the authorities of University of Abobo adjame in Côte d'Ivoire. The authors acknowledge Yapi Daniel and Kassi Lambert, technicians in UFR-STA of the University of Abobo Adjame in Cote d'Ivoire, for their cooperation and their contribution for technical realization of this work.

\section{REFERENCES}

Alabi MO1, Anuonye JC. 2007. Nutritional and sensory attributes of soysupplemented cereal meals. Nigerian Food Journal, 25: 100-110.

Akinyede AI, Amoo IA. 2009. Chemical and functional properties of full fat and defatted Cassia fistula seed flours. Pak. J. Nutr., 8(6): 765-769.

AOAC (Association of Official Analytical Chemists). 1990. Official Method of Analysis $\left(15^{\text {th }}\right.$ edn). Association of Official Analytical Chemists: Washington DC.

Asp N, Björck I. 1989. Nutritional properties of extruded foods. In Extrusion Cooking, Mercier C, Linko P, Harper JM (Eds). St. Paul MN: American Association of Cereal Chemists; 399434.

Barampama Z, Simard RE. 1994. Oligosaccharides, antinutritional factors, and protein digestibility of dry beans as affected by processing. J. Food Sci., 59: 833-838.

Barhisel R, Bertsch PM. 1982. Digestion with perchloric-nitric acids. In Methods of soil Analysis. (Page, A. L. , Ed). Am. Soc. Agronomist. Agron, 9: 279-280.

Bertrand G, Thomas P. 1910. Guide pour les Manipulations de Chimie Biologie. Dunod: Paris; 468p. 
Bressani R. 1975. Nutritional contribution of soy protein to food system. J. Am. Oil Chem. Soc., 52: 254-262.

Egounlety M. 1996. Production des aliments de sevrage enrichis. Communication Scientifique au Cinquième Cours Régional en Nutrition \& en Sciences Alimentaires. Cotonou, Bénin, 12 Août06 Septembre. 21p.

Egounlety M. 2001. Sensory evaluation and nutritive value of tempe snacks in West Africa. Int. J. Food Prop., 4(3): 513522

Egounlety M. 2003. Processing of velvet bean (Mucuna pruriens var utilis) by fermentation. Tropical and Subtropical Agroecosystems, 1: 173 - 181.

Eka OU. 1978. Chemical evaluation of nutritive value of soy paps and porridges, the Nigerian weaning foods. Food chem., 3: $199-206$.

Fernando DG, Leonard V, Heiks CB. 1998. Tocopherol contents and other seed quality traits in several Brassica species, in Advances in Plant Lipid Research J. Sanchez E, Cerda-Olmedo E, MartinezFore (Eds), université de Séville: Espagne; 436-438.

Ferreira RB, Melo TS, Teixeira AN. 1995. Catabolism of the seed storage proteins from Lupinus albus. Fate globulins during germination and seedling growth. Austr. J. Plant Physiol., 76: 373-381.

Ferrier LK, Bird D, Wei LS, Nelson AI. 1975. Weaning food prepared from whole soybean and bananas by drum drying. Arch. Latinoam. Nutr., Special edition: 281-295.

Greenberg P, Harting H.1998. The Whole Soy Cook Book. Three Rivers Press: New York; p.17.

Guiro AT, Sall MG, Kane O, N'Diaye AM, Diarra D, Sy MTA. 1987. Protein-calorie malnutrition in Senegalese children. Effects of rehabilitation with a pearl millet weaning food. Nutr. Rep. Int., 36: 1071.
Harper, JM., 1981. Extrusion of foods (Vol. 2). CRC Press, Inc.: Boca-Raton, FL.

Hoover R, Sosulski FW. 1985. Studies on the functional characteristics and digestibility of starches from Phaseolus vulgaris biotypes. Starch, 37: 181-191.

Ikujenlola VA, Fashakin JB. 2005. The physico-chemical properties of complementary diet prepared from vegetable proteins. J. Food Agric. Environ., 3: 23-26.

Inyang CU, Idoko CA. 2006. Assessment of the quality of "Ogi" made from malted mallet. Af. J. Biotechnol., 5: 2334-2337.

Inyang CU, Zakari UM. 2008. Effect of Germination and Fermentation of Pearl Millet on Proximate, Chemical and Sensory Properties of Instant "Fura"- A Nigerian Cereal Food. Pak. J. Nutr. 7(1): 9-12.

Iwe MO, Onuh JO. 1992. Functional and Sensory properties of soybean and sweet potato flour mixtures. Lenbenson, Wens UTechnol., 569 - 573.

Jachmanian L, Perifanova-Nemska M, Grompone MA., Mukherjee KD. 1995. Germination rapeseed as biocatalyst: hydrolysis of exogenous and endogenous triacylglycerols. J. Agri. Food Chem., 43: 2992-2996.

Kanu PJ, Sandy EH, Kandeh BAJ, Bahsoon JZ, Huiming Z. 2009. Production and Evaluation of Breakfast Cereal-Based Porridge Mixed with Sesame and Pigeon Peas for Adults. Pak. J. Nutr. 8(9): 1335-1343.

Kluvitse MY. 1999. Nutritional, physicochemical and sensory evaluation of extrusion-cooked cereal/legume weaning formulations. $\mathrm{PhD}$ thesis, Athens, Georgia, p. 161.

Kong BW, Kim JI, Kim MJ, Kim JC. 2003. Porcine pancreatic a-amylase hydrolysis of native starch granules as a function of granule surface area. Biotech. Progress, 19: 1162-1166. 
Ljungqvist BG, Mellander O, Svandberg USO. 1981. Dietary bulk as a limiting factor for nutrient intake in pre-school children. I. A problem description. $J$. Trop. Pediatr., 27: 68 - 73.

Livesey G. 1995. Metabolizable energy of macronutrients. Am. J. Clin. Nutr. 62 (sppl.): 1135S-1142S.

Nnam NM. 2000. Evaluation of effect of sprouting on the viscosity, proximate composition and mineral content of hungary rice, acha (Digiteria exilis) flours. Nig. Food J., 18: 57-62.

Nnam NM. 2002. Evaluation of complementary foods based on maize, groundnut, pawpaw and mango flours blends. Nigerian J. Nutr. Sci., 22: 8-18.

Malleshi NG, Daodu MA, Chandrasekhar A. 1999. Development of weaning food formulation based on malting and roller drying of sorghum and cowpea. Int. J. Food Sci. Tech., 24: 511-519.

Raham EH, Aal MH. 1986. Changes in gross chemical composition with emphasis on lipid and protein fractions during germination of fenugreek seeds. Food Chem., 22: 193-198.
Sauerweli RN, Mulder JA, Mulder L, Lowe B, Peshu N, Demacker PNM, Van der Meer JW M, Marsh K. 1997. Inflammatory mediators in children with protein energy malnutrition. Am. J. Clin. Nutr., 65: 1534-1539.

Topping DL, Clifton PM. 2001. Short-chain fatty acids and human colonic function: roles of resistant starch and nonstarch polysaccharides. Physiol. Rev., 81: 1031-1064.

Van der Merwe B, Erasmus C, Taylor JRN. 2001. African maize porridge: a food with slow in vitro starch digestibility. Food chem., 72: 191-203.

Wu YV, Wall JS. 1980. Lysine content of protein increased by germination of normal and high-lysine sorghum. J. Agri. Food Chem., 28: 455-458. 